\title{
Faktor-Faktor yang Mempengaruhi Minat Mahasiswa Akuntansi Mengikuti Ujian Sertifikasi Chartered Accountant (CA) (Studi Kasus Pada Politeknik Negeri Manado)
}

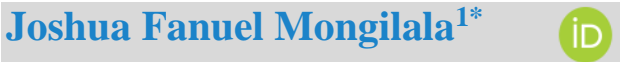 \\ ${ }^{123}$ Fakultas Ekonomika dan Bisnis, Universitas Kristen Satya Wacana \\ *Corresponding author
}

\section{Abstrak}

Chartered Accountant (CA) Indonesia merupakan kualifikasi akuntan profesional sesuai panduan standar internasional. Manfaat penelitian ini adalah sebagai bahan masukan bagi: para mahasiswa akuntansi yang berminat mengikuti ujian sertifikasi CA, IAI dalam pengembangan penyelenggaraan ujian sertifikasi CA, Jurusan Akuntansi Politeknik Negeri. Pendekatan yang digunakan adalah pendekatan kualitatif bersifat induktif, guna mendeskripsikan faktor-faktor yang mempengaruhi minat mahasiswa akuntansi yang berminat mengikuti ujian sertifikasi CA. Teknik pengambilan data yang dilakukan yaitu melalui observasi partisipasi pasif (passive participation observation), wawancara tidak terstruktur (unstructured interview) terhadap 5 (lima) informan kunci (key informant), dan dokumentasi. Analisis data dilakukan dengan menggunakan teknik analisis kualitatif melalui aktivitas reduksi data, penyajian data, dan penarikan kesimpulan/verifikasi. Hasil penelitian menunjukkan bahwa minat tersebut dipengaruhi oleh faktor norma subyektif yang meliputi suatu dorongan dan kemauan dari diri sendiri; faktor sikap terhadap perilaku yang meliputi berpeluang besar secara terbuka dalam kompetisi masuk dan berkarir di perusahaan lokal dan asing, dapat mengembangkan diri sebagai akuntan profesional sesuai dengan standard internasional; faktor kontrol perilaku persepsian meliputi keyakinan mengikuti ujian sertifikasi walaupun memerlukan alokasi waktu dan biaya yang cukup besar, dengan pertimbangan waktu bekerja sambil belajar dapat dilakukan secara bersama-sama atau memilih menunda bekerja karena ingin mempersiapkan diri dalam mengikuti ujian sertifikasi CA, sedangkan besaran biaya dianggap hal yang wajar.

Kata Kunci : Kualifikasi Akuntan, Mahasiswa Akuntansi, Minat, Ujian Sertifikasi

\begin{abstract}
Chartered Accountant (CA) Indonesia is a professional accountant qualification according to international standard guidelines. The benefit of this research is as input for: accounting students who are interested in taking the CA certification exam, in developing the implementation of the CA certification exam, State Polytechnic Accounting Department. The approach used is an inductive qualitative approach, in order to describe the factors that influence the interest of accounting students who are interested in taking the CA certification exam. Data collection techniques are carried out through passive participation observation, unstructured interviewswith 5 (five) key informants, and documentation. Data analysis was performed using qualitative analysis techniques through data reduction activities, data presentation, and conclusion / verification. The results showed that the interest is influenced by subjective norm factors which include an encouragement and a will from oneself; attitudes towards behavior factors, which include open opportunities in entry competitions and careers in local and foreign companies, being able to develop themselves as professional accountants in accordance with international standards; Perceived behavioral control factors include the belief in taking a certification exam even though it requires a fairly large allocation of time and costs, with the consideration that working time while studying can be done together or choosing to postpone work because they want to prepare themselves for the CA certification exam, while the amount of the cost is considered to be reasonable.
\end{abstract}

Keywords: Chartered Accountant. Accounting Students, Interest, Certification Exam

$\begin{array}{ll}\text { History: } & \text { Publisher: Undiksha Press } \\ \text { Received: 16 April } 2021 & \text { Licensed: This work is licensed under } \\ \text { Revised: 26 Juni } 2021 & \text { a Creative Commons Attribution 3.0 License } \\ \text { Accepted: 28 Juni } 2021 & \text { CC OP } \\ \text { Published: 30 Juni } 2021 & \text { SA }\end{array}$




\section{Pendahuluan}

Fungsi dan posisi dalam lingkup profesionalisme dibidang akuntansi semakin berkembang dan memiliki peranan yang penting dalam menghadapi persaingan global, khususnya di Indonesia. Fungsi dan posisi tersebut berpengaruh besar terhadap peranan dan kemampuan bagi pihak-pihak yang kompeten dibidang akuntansi dalam sektor komersial dan sektor publik serta dalam segala bidang, apalagi jika dilihat dari kebutuhan dunia internasional sekarang ini. Kemampuan yang memiliki kompetensi berdaya saing harus ditunjang dengan pendidikan profesional berkelanjutan sebagai akuntan profesional dan berstandar internasional, seperti yang ditetapkan dalam Peraturan Menteri Keuangan (PMK) Republik Indonesia (RI) PMK Nomor 25/PMK.01/2014 Tentang Akuntan Beregister Negara.

Menteri Keuangan Republik Indonesia, (2014) menetapkan Peraturan Menteri Keuangan Nomor 25/PMK.01/2014 Tentang Akuntan Beregister Negara yang didasarkan atas pertimbangan dari Undang-Undang Nomor 34 Tahun 1954 Pasal 3 Ayat (4) Tentang Pemakaian Gelar Akuntan (Accountant), tiap-tiap akuntan berijazah wajib mendaftarkan namanya untuk dimuat dalam suatu register negara yang diadakan oleh Kementerian Keuangan dan Pasal 6, Penyelenggaraan Pendaftaran Akuntan Pada Register Negara belum mengatur mengenai pembinaan profesi akuntan, yang kemudian telah ditetapkan dengan Keputusan Menteri Keuangan Nomor 331/KMK.017/1999 Tentang Penyelenggaraan Pendaftaran Akuntan Pada Register Negara yang belum mengatur mengenai pembinaan profesi akuntan dan belum memberikan perlindungan sepenuhnya, yang selanjutnya dicabut setelah pemberlakuan PMK No.25/PMK.01/2014. Pemberlakuan PMK tersebut dapat memberikan satu jaminan, kepercayaan, dan perlindungan untuk menghadapi tantangan profesi dalam perekonomian global, seperti halnya kualifikasi akuntan profesional yang ditetapkan oleh Ikatan Akuntan Indonesia (IAI) dengan istilah Chartered Accountant (CA) yang sesuai dengan panduan standar internasional. Tentunya dapat memberikan suatu peluang yang tidak terbatas, pengakuan, dan pencapaian penting bagi seorang akuntan profesional yang berkualitas tinggi.

IAI, (2014) menyatakan bahwa Ikatan Akuntan Indonesia sebagai organisasi profesi terdepan yang memiliki visi dalam pengembangan pengetahuan dan praktek akuntansi, manajemen bisnis dan publik yang mengutamakan etika dan tanggung jawab secara umum, dalam aspek secara nasional dan internasional, bermaksud dan memiliki tujuan untuk menghimpun, mengembangkan, dan mendayagunakan potensi akuntan Indonesia dalam pembangunan nasional serta mendarmabaktikan bagi kepentingan bangsa dan negara; dengan Fungsi IAI sebagai wadah komunikasi dalam berbagai aspek dan tanggung jawab yang bersinergi secara serasi, seimbang, dan selaras. Sejalan dengan maksud, tujuan, dan fungsi tersebut, sehingga IAI menyelenggarakan Ujian Sertifikasi CA yang berdasarkan ketentuan Internastional Federation of Accountant, Anggaran Rumah Tangga dan Anggaran dasar, peraturan perundang-undangan serta aturan lain yang ditentukan; dan memenuhi prinsip-prinsip sebagai panduan yaitu, objektivitas, kompetensi, integritas, independen, fairness, transparan, bertanggungjawab, dan adil. IAI, (2014) menyatakan berbagai aspek dalam kedudukan fungsi dan posisi CA melingkupi: Manajerial, Operasional, Management Control, Accounting dan Stakeholder Communications, Sektor Publik, Akademik, dan Auditor.

CA sebagai kualifikasi akuntan profesional berstandar internasional dalam era globalisasi sekarang ini, semakin banyak diminati oleh para lulusan akuntansi yang kompeten, terutama pengembangan karir dalam berbagai sektor dalam hal ini tenaga dosen akuntansi sebagai tenaga pengajar atau tenaga pendidik akuntansi, namun ada juga yang kurang berminat. Hal inilah yang membuat peneliti tertarik melakukan penelitian mengenai faktor-faktor yang mempengaruhi minat mahasiswa akuntansi dalam mengikuti ujian sertifikasi CA, khususnya mahasiswa akuntansi di Politeknik Negeri Manado. Ada beberapa 
faktor yang mempengaruhi minat mahasiswa akuntansi mengikuti ujian sertifikasi CA, yang dapat dibuktikan melalui berbagai hasil penelitian dari beberapa peneliti. Vidalita, (2015) menemukan bahwa salah satu faktor yang mempengaruhi mahasiswa akuntansi dalam mengikuti ujian sertifikasi CA adalah motivasi untuk mengembangkan karir. Sapitri \& Yaya, (2015) mengatakan faktor yang mempengaruhi mahasiswa akuntansi untuk mengikuti ujian sertifikasi CA adalah motivasi untuk mencari ilmu. Ilmiha \& Syafrizal, (2017) menemukan bahwa salah satu faktor yang mempengaruhi mahasiswa akuntansi untuk mengikuti ujian sertifikasi CA adalah motivasi ekonomi. Sumaryono \& Sukanti, (2016) menemukan bahwa lulusan akuntansi tidak memiliki niat untuk mengambil sertifikasi CA karena tidak mengetahui secara spesifik mengenai chartered accountant. Laksmi \& Suciati, (2018) menyatakan bahwa lulusan akuntansi tidak berniat untuk mengikuti sertifikasi akuntan profesional, berhubung tidak memiliki keterampilan, sumber daya, dan peluang.

Hidayat, Syarif \& Asroi, $(2013,87)$ menyebutkan minat adalah suatu hal yang berasal dari perasaan yang berupa kegemaran terhadap suatu hal yang dapat memunculkan kegiatankegiatan tertentu. Sumaryono \& Sukanti, (2016) mengungkapkan minat sarjana akuntansi mengikuti sertifikasi CA merupakan rancangan dan harapan mereka untuk memperoleh sertifikat CA. Berdasarkan pada TPB (Theory of Planned Behavior) yang dicetuskan oleh Ajzen pada Tahun 2012 diterapkan untuk mengetahui faktor-faktor seseorang dalam memilih karier, artinya minat untuk bersikap kenyataannya ditentukan oleh niat seseorang. Minat para mahasiswa akuntansi dalam mengikuti ujian sertifikasi CA berdasarkan hasil penelitian terdahulu dipengaruhi oleh berbagai faktor dan kegunaan yang sangat berpengaruh terhadap kualitas akuntan profesional yang kompeten dan dapat berkompetisi di dalam negeri maupun internasional akuntansi. Agustina \& Yanti, (2015) mengatakan bahwa mahasiswa akuntansi adalah individu yang mempunyai pemahaman mengenai akuntansi dengan sangat baik

Menteri Hukum dan Hak Asasi Manusia Republik Indonesia, (2014) menetapkan Peraturan Pemerintah Nomor 4 Tahun 2014 BAB I Pasal 1 ayat (10) Tentang Penyelenggaraan Pendidikan Tinggi dan Pengelolaan Perguruan Tinggi, Politeknik adalah Perguruan Tinggi yang menyelenggarakan pendidikan vokasi dalam rumpun berbagai ilmu pengetahuan dan/atau teknologi dan jika memenuhi syarat, politeknik dapat menyelenggarakan pendidikan profesi. Menteri Hukum dan Hak Asasi Manusia Republik Indonesia, (2012) menetapkan Undang-Undang Nomor 12 Tahun 2012 BAB II Pasal 16 ayat (1) Tentang Pendidikan Tinggi, Pendidikan Vokasi merupakan Pendidikan Tinggi program diploma yang menyiapkan mahasiswa untuk pekerjaan dengan keahlian terapan tertentu sampai program sarjana terapan. Demikian juga dengan Politeknik Negeri Manado sebagai penyelenggara pendidikan vokasi yang memiliki visi untuk menghasilkan sumber daya manusia yang memenuhi standar kompetensi global serta menjadi pusat pelatihan dan penerapan teknologi; dan misinya antara lain yaitu agar dapat mengembangkan mutu pelayanan pendidikan secara profesional untuk menghasilkan lulusan yang berkualitas serta berdaya saing sesuai standar kompentensi nasional dan internasional, mengembangkan dan memberdayakan potensi tenaga kerja kependidikan secara berkelanjutan, dan meningkatkan dan mengembangkan pendidikan yang relevan dengan kebutuhan masyarakat. Implementasinya ada pada Politeknik Negeri Manado, yang memiliki tenaga pengajar yang kompeten dan bersertifikasi Chartered Accountant (CA) agar dapat menghasilkan sumber daya manusia yang dapat berkompetisi di era Masyarakat Ekonomi ASEAN (MEA) atau ASEAN Economic Community (AEC) dan internasional sesuai Kode Etik IAI.

Berdasarkan latar belakang tersebut, maka penulis merumuskan masalah atas penelitian ini yaitu faktor-faktor apa yang mempengaruhi minat mahasiswa akuntansi dalam mengikuti ujian sertifikasi CA? (Studi Kasus pada Politeknik Negeri Manado). 
Manfaat penelitian ini adalah sebagai bahan masukan bagi: para mahasiswa akuntansi yang berminat mengikuti ujian sertifikasi CA, IAI dalam pengembangan penyelenggaraan ujian sertifikasi CA, Jurusan Akuntansi Politeknik Negeri.

Minat

Hidayat, Syarif \& Asroi $(2013,87)$ menyebutkan minat adalah suatu hal yang berasal dari perasaan yang berupa kegemaran terhadap suatu hal yang dapat memunculkan kegiatankegiatan tertentu. Slameto $(2013,57)$ mengungkapkan bahwa minat adalah keinginan yang kuat untuk memperhatikan dan mengingat beberapa kegiatan yang diminati oleh individu secara konsisten disertai rasa senang. Saraswati \& Baridwan, (2012) mengungkapkan bahwa minat merupakan keinginan hati yang tinggi atas sesuatu yang muncul akibat kebutuhan tertentu.

Schunk (2012, 316-321) mendeskripsikan aspek-aspek minat sebagai berikut: sikap umum terhadap suatu hal, preferensi terhadap suatu hal, kesadaran spesifik untuk menyukai suatu hal, kesenangan personal terhadap konten suatu hal, adanya kepentingan atau signifikansi personal terhadap suatu hal, dan partisipasi dalam suatu hal; artinya dari masingmasing aspek tersebut menjelaskan mengenai perasaan suka dan senang kemudian menyukai serta diberikan penilaian yang selanjutnya dilakukan aktivitas dalam hubungannya dengan suatu hal sebagai akibat dari daya tarik.

Smadi, (2012) menyatakan bahwa aspek-aspek sebagai faktor yang mempengaruhi minat dikelompokkan sebagai berikut: faktor keinginan jasmani dan rohani; faktor motif sosial seperti munculnya minat akibat adanya keinginan untuk memperoleh pengakuan dan penghargaan dilingkungan sekitar; faktor emosional, merupakan tingkatan niat seseorang terhadap sesuatu hal.

Minat dapat disimpulkan sebagai keinginan yang kuat untuk bertindak karena daya tarik suatu hal seperti kegiatan, aktivitas, dan kebutuhan guna memuaskan hasrat hati seseorang. Keinginan karena daya tarik muncul akibat dari sikap positif yang pada akhirnya dilakukan untuk memuaskan diri sendiri.

\section{Mahasiswa Akuntansi}

Agustina \& Yanti, (2015) mengatakan bahwa mahasiswa akuntansi adalah lulusan yang mempunyai pemahaman mengenai akuntansi dengan sangat baik. Menteri Keuangan Republik Indonesia, (2014) menetapkan Peraturan Menteri Keuangan Nomor 25/PMK.01/2014 Tentang Akuntan Beregister Negara BAB II Pasal 4 ayat (2), Untuk dapat mengikuti ujian sertifikasi akuntan profesional, seseorang harus memenuhi salah satu persyaratan sebagai berikut: a. memiliki pendidikan paling rendah diploma empat (D-IV) atau sarjana (S-1) di bidang akuntansi yang diselenggarakan oleh perguruan tinggi Indonesia atau luar negeri yang telah disetarakan oleh instansi yang berwenang sesuai dengan ketentuan peraturan perundang-undangan di bidang pendidikan; b. memiliki pendidikan magister (S-2) atau doktor (S-3) yang menekankan penerapan praktik-praktik akuntansi dari perguruan tinggi Indonesia atau perguruan tinggi luar negeri yang telah disetarakan oleh instansi yang berwenang sesuai dengan ketentuan perundang-undangan di bidang pendidikan; c. mengikuti pendidikan profesi akuntansi; atau d. memiliki sertifikat teknisi akuntansi level 6 (enam) berdasarkan kerangka kualifikasi nasional Indonesia sesuai dengan ketentuan peraturan perundang-undangan. Abidin \& Ervanto, (2015) menyatakan bahwa lulusan akuntansi S-1 dapat berkarir atau melanjutkan ke jenjang S-2 atau mengikuti Pendidikan Profesi Akuntansi (PPAk) untuk memperoleh gelar akuntan. Riswandari, (2017) mengatakan bahwa sarjana akuntansi bebas memilih karier di bidang akuntansi yang diinginkan, seperti akuntan publik, akuntan perusahaan atau akuntan manajemen, akuntan pendidik, dan akuntan pemerintah.

Berdasarkan definisi, ketetapan, dan pernyataan tersebut, dapat disimpulkan bahwa mahasiswa akuntansi adalah mahasiswa yang memiliki kompetensi dalam bidang akuntansi sesuai program pendidikan tinggi dan gelar berdasarkan ketentuan peraturan perundang- 
undangan yang berlaku dan memiliki kemandirian dalam menentukan praktik keprofesian dibidang tersebut.

\section{Chartered Accountant}

IAI, (2019) menyatakan bahwa Chartered Accountant Indonesia yang ditetapkan dengan sebutan CA merupakan kualifikasi akuntan profesional sesuai panduan standar internasional. Kualifikasi CA ditetapkan untuk menjaga dan meningkatkan kepercayaan, memberikan perlindungan, mampu menghadapi tantangan profesi, dan memiliki daya saing sebagai jaminan peningkatan kualitas yang profesional di era globalisasi. Kualifikasi untuk mendapatkan gelar CA yaitu personal yang telah memperoleh sertifikat CA Indonesia dari IAI; termasuk anggota IAI; mempunyai keahlian dan/atau melakukan penerapan keprofesian di bidang akuntansi, seperti sebagai pelaku akuntan publik minimal selama tiga tahun dalam tujuh tahun terakhir, maupun pada sektor publik, korporasi, dan pendidikan. Jika telah memperoleh sertifikat CA, maka seseorang dapat melakukan praktek selaku Akuntan Profesional berdasarkan kompetensi khusus dan utama CA. Syarat untuk dapat ikut serta dalam ujian sertifikasi CA, yaitu: terdaftar sebagai anggota IAI; mencapai salah satu ketentuan pendidikan yaitu: minimal Diploma Empat atau Sarjana starta satu jurusan akuntansi dengan penyelenggara perguruan tinggi baik dalam negeri maupun luar negeri yang ditetapkan oleh lembaga yang berhak berdasarkan peraturan dan ketentuan di bidang pendidikan, lulus pendidikan Program Profesi Akuntan (PPAk), atau mempunyai sertifikat level enam sesuai peraturan atas konteks kompetensi Nasional Indonesia.

IAI, (2014) menyatakan berbagai aspek dalam kedudukan fungsi dan posisi CA melingkupi: Manajerial, Operasional, Management Control, Accounting dan Stakeholder Communications, Sektor Publik, Akademik, dan Auditor. Berbagai fungsi dan posisi tersebut, khususnya dalam lingkup akademik, seorang CA memiliki kompetensi sebagai dosen atau tenaga pengajar, pimpinan fakultas/universitas.

Chartered Accountant (CA) dapat disimpulkan sebagai profesi akuntan yang diperoleh melalui ujian sertifikasi akuntan oleh IAI sebagai organisasi profesi dan wadah komunikasi terutama sebagai badan regulasi di Indonesia. CA dapat diikuti oleh lulusan S-1/DIV akuntansi melalui ujian langsung ataupun melalui Pendidikan Profesi akuntan (PPAk), sedangkan bagi lulusan S-1/DIV yang bukan lulusan akuntansi dapat diperoleh melalui PPAk setelah didahului matrikulasi. CA dalam lingkup akuntan pendidik merupakan salah satu fungsi dan posisi yang memiliki kompetensi di bidang akuntansi dan berdaya saing tinggi sebagai tenaga pengajar profesional sesuai Kode Etik IAI.

Theory of Planned Behaviour (TPB)

Penelitian ini menggunakan teori TPB (Theory of Planned Behavior). Mihartinah \& Coryanata, (2019) mengatakan bahwa Theory of Planned Behavior (TPB) adalah teori yang dapat menilai perilaku seseorang berdasarkan faktor dari TPB. Pada tahun 1988 Theory of Reasoned Action (TRA) dikembangkan oleh Icek Ajzen yang kemudian menjadi Theory of planned Behavior (TPB). TPB mengidentifikasi bahwa kontrol atas sikap persepsian dipenuhi guna mengendalikan sikap perilaku yang kemungkinan tidak dilakukan secara total oleh personal maupun kelompok. Sumaryono \& Sukanti, (2016) mengatakan bahwa Model TPB yang dicetuskan oleh Ajzen pada Tahun 2012, diterapkan untuk mengetahui faktor-faktor seseorang dalam memilih karier. Artinya, minat untuk bersikap kenyataannya ditentukan oleh niat seseorang. Ajzen $(2012,438)$ mengatakan bahwa TPB merupakan konteks kerja yang berfungsi untuk merancang intervensi dan penilaian efektivitas intervensi guna membarui ketetapan sebagai dasar kinerja perilaku, serta memandu dalam menetapkan faktor-faktor apa yang dapat menunjang atau membatasi kinerja perilaku dan kemampuan yang ada. Penentu suatu perilaku adalah minat, yang merupakan bagian dari personil secara pribadi dengan didasarkan pada keinginan untuk bertindak secara langsung atau perilaku aktual (actual 
behavior). Penilaian perilaku seseorang menurut TPB dipengaruhi oleh minat yang didasarkan oleh faktor-faktor, yaitu: Sikap terhadap perilaku, Norma subjektif, dan Kontrol perilaku persepsian.

Berhubungan dengan TPB tersebut, jika seorang mahasiswa akuntansi memiliki minat untuk mengikuti ujian sertifikasi $\mathrm{CA}$, itu artinya merupakan sebuah perilaku yang dipengaruhi oleh minat individu berdasarkan faktor norma subjektif, sikap terhadap perilaku, dan kontrol perilaku persepsian. Maulana \& Saud, (2016) mengatakan sikap adalah kecenderungan untuk bertindak secara positif atau negatif perilaku spesifik. Wanarta \& Mangoting, (2014) menyatakan bahwa norma subjektif memfokuskan pada tuntutan sosial yang lebih dipahami sebagai pelaksanaan perilaku spesifik atas keyakinan seseorang dalam bertindak untuk menyetujui atau menolak dorongan dari pihak yang memberi referensi. Maulana \& Saud, (2016) menyatakan bahwa kontrol perilaku persepsian berfungsi sebagai peran yang berdasarkan ketetapan atau keyakinan kontrol.

\section{Metode}

Teknik pengambilan data yang dilakukan oleh peneliti yaitu melalui observasi, wawancara, dan dokumentasi. Observasi yang digunakan adalah observasi partisipasi pasif (passive participation observation). Peneliti dalam hal ini tidak ikut secara langsung dengan kegiatan mahasiswa sebagai informan kunci, tetapi hanya mengamati aktivitasnya, agar supaya lebih memperkuat dan akurat hasil penelitian. Observasi yang dilakukan oleh peneliti terbagi atas dua tahap, yaitu observasi pasif pendahuluan pada saat survei pendahuluan ke Jurusan Akuntansi Prodi S1 Terapan Akuntansi Keuangan Politeknik Negeri melalui pengamatan di lokasi penelitian dan observasi pasif lanjutan pada saat wawancara untuk pengambilan data primer seperti, pengambilan dokumen-dokumen yang harus diambil langsung oleh peneliti sebagai data sekunder untuk menunjang data analisis penelitian, sekaligus sudah termasuk kategori penelitian yang nyata dan akurat karena ditangkap langsung melalui ucapan dan tindakan informan kunci untuk menunjang analisis data penelitian.

Jenis wawancara yang digunakan dalam penelitian ini adalah wawancara tidak terstruktur (unstructured interview), artinya peneliti berinteraksi langsung dengan sumber data dan telah mempersiapkan pedoman wawancara berupa garis-garis besar permasalahan yang akan ditanyakan untuk memperoleh hasil wawancara yang lebih mendalam secara bebas terhadap para mahasiswa Jurusan Akuntansi di Politeknik Negeri Manado. Pertanyaanpertanyaan dalam pedoman wawancara yang telah diformulasikan untuk diajukan kepada informan kunci dapat juga berkembang selama proses wawancara berlangsung, artinya peneliti memberikan kebebasan untuk memberikan jawaban apabila dalam wawancara tersebut berkembang pertanyaan-pertanyaan yang baru dari peneliti. Persiapan wawancara dalam penelitan selain telah menyiapkan instrument penelitian untuk menunjang kelancaran wawancara tersebut, peneliti menggunakan alat-alat bantu guna merekam dengan baik sebagai bukti telah melakukan wawancara guna meningkatkan keabsahan dalam melakukan pengumpulan data penelitian. Peralatan tersebut yaitu buku catatan, handphone, pita rekaman atau tape recorder, camera.

Dokumentasi digunakan untuk memperoleh data sekunder sebagai pendukung penelitian dan mendukung teknik wawancara, yaitu pendapat dan catatan penulis sendiri, foto-foto dokumentasi, ditunjang dengan dokumentasi literatur dan sumber dari internet, perundang-undangan dan peraturan-peraturan pemerintah Republik Indonesia yang relevan dengan kebijakan lulusan akuntansi, serta aturan dari IAI.

Sumber data atau informan sebagai narasumber dalam penelitian ini adalah para mahasiswa di Jurusan Akuntansi Prodi S1 Terapan Akuntansi Keuangan Politeknik Negeri Manado. Penentuan informan kunci (key informant) yang akan digunakan dalam penelitian 
ini menggunakan teknik sampling bertujuan (purposive sampling) melalui penentuan informan kunci terhadap para mahasiswa yang berjumlah 5 (lima) orang.

Data penelitian diperoleh dari informan kunci atau narasumber atas pemahaman, pandangan, dan pernyataan serta ditunjang dengan sumber-sumber dokumentasi yang akurat dan terpercaya. Analisis data lebih difokuskan pada selama proses di lapangan bersamaan dengan pengumpulan data. Proses analisis data dilakukan mulai dari sebelum di lapangan, saat di lapangan, dan penarikan kesimpulan dan verifikasi. Analisis sebelum di lapangan di lakukan terhadap data hasil penelitian terdahulu dan sumber-sumber data sekunder yang diperlukan, seperti data mahasiswa di Jurusan Akuntansi Prodi S1 Terapan akuntansi Keuangan Politeknik Negeri Manado; sedangkan analisis data di lapangan mulai pada saat wawancara kepada 5 (lima) mahasiswa tersebut terhadap jawaban-jawaban dari informan kunci dan jika ada jawaban yang belum memuaskan serta relevan dengan fokus penelitian, maka akan dilanjutkan dengan pertanyaan lagi untuk mendapatkan jawaban yang meyakinkan dan akurat.

Teknik analisis data dalam penelitian ini menggunakan analisis kualitatif, diawali dari langkah-langkah analisis data di lapangan mulai dari pengumpulan data berlangsung dan setelah selesai pengumpulan data, dilakukan antisipasi seperti: Reduksi data (data reduction) yaitu menentukan data yang sesuai dan signifikan sebagai dasar memperluas analisis penelitian. Dalam penelitian ini reduksi data dilakukan dengan memilah, memotong, mengkode, menjelaskan, dan memodifikasi data kasar yang diperoleh dari pengambilan data berdasarkan transkrip wawancara dan observasi yang dilakukan terhadap mahasiswa Jurusan Akuntansi Prodi S1 Terapan Akuntansi Keuangan Politeknik Negeri Manado dan dokumendokumen yang relevan. Pengkodean menggunakan simbol dalam suatu struktur yang rinci secara terpadu untuk hasil wawancara dan catatan-catatan yang objektif sekaligus mengklasifikasikan sebagaimana adanya. Penyimpanan data melalui penggunaan komputer dan laptop dengan sistematika penulisan sesuai buku panduan Tata Tulis Tugas Akhir 2020; Penyajian data (data display) dengan menggunakan teks yang bersifat naratif melalui tulisan deskriptif, bagan, flowchart, dan sejenisnya. Setelah tahap reduksi data dilanjutkan dengan penyajian data mengenai faktor-faktor yang mempengaruhi minat mahasiswa akuntansi mengikuti ujian sertifikasi CA. Selain pemaparan dalam bentuk naratif, untuk data mahasiswa tersebut disajikan dalam bentuk tabel dengan kategori seutuhnya sebagai mahasiswa dan kategori kedudukan dan posisinya sekaligus ada dalam lingkup perguruan tinggi; dan Penarikan kesimpulan/verifikasi (conclusion drawing/verification) yang dipaparkan pada awalnya masih belum pasti dan jika ada perubahan yang didukung oleh data-data serta fakta yang otentik atau akurat pada tahap pengumpulan data, maka kesimpulan tersebut yang menjadi pembuktian atas penelitian. Kesimpulan ini akan menjawab fokus penelitian berdasarkan hasil analisis data yang dilakukan penulis, selanjutnya menjadi rekomendasi atas hasil penelitian.

\section{Hasil dan Pembahasan}

\section{Profil Politeknik Negeri Manado}

Politeknik Negeri Manado merupakan salah satu perguruan tinggi politeknik di Indonesia yang dibangun oleh pemerintah dalam rangka memperluas akses pemerataan pendidikan untuk meningkatkan percepatan pembangunan secara merata dan memiliki kompetensi pada bidang masing-masing. Diresmikan oleh presiden RI pada tanggal 19 Juli 1988 dengan nama Politeknik Engginering Universitas Samratulangi Manado dengan menyelenggarakan pendidikan program Diploma II dengan 4 (empat) Jurusan yakni: Jurusan Teknik Sipil, Teknik Elektro, Teknik Mesin, dan Tata Niaga. Secara otonom, Politeknik Engginering Universitas Samratulangi Manado menjadi mandiri dalam penyelenggaraan 
pendidikan dan memisahkan diri dari Universitas Samratulangi Manado berdasarkan Surat Keputusan Mendikbud Nomor: 016/0/1999 Tanggal 18 Januari 1999 dan berubah nama menjadi Politeknik Negeri Manado dengan kepemimpinan 7 (tujuh) orang direktur dengan masa jabatan sebagaimana di bawah ini, yakni : DR.Ir.Ruddy Tenda, Prof. Ir Bonnie F. Sompie, MS., Ir. Marhany V.P. Pua, Enos V. Nixson Munaiseche, SE., Ir Jemmy Julies Rangan, MT., Ir.Evert N.Slat, MT., dan terakhir Dra.Mareyke Alelo, MA sampai sekarang. Sampai dengan Tahun 2021, Politeknik Negeri Manado telah memiliki ijin penyelenggaraan program studi yang terdiri program studi dengan jenjang diploma IV yakni: Teknik bangunan gedung, Teknik perumahan dan pemukiman, Manajemen bisnis, Teknik informatika, Teknik listrik, Akuntansi keuangan dan Perhotelan, serta program studi jenjang diploma III yakni : Teknik sipil, Teknik computer, Teknik listrik, Teknik mesin, Akuntansi, Akuntansi perpajakan, Administrasi bisnis, Marketing perhotelan, Parawisata bawah laut dan urusan perjalanan wisata. Politeknik Negeri Manado memiliki lahan kampus luas +11 ha yang terdiri dari kampus A yang berlokasi di kelurahan Buha Kecamatan Mapanget dengan luas +9 ha dan kampus B di Tateli Kabupaten Minahasa dengan luas +2 ha untuk penyelenggaraan program studi Pariwisata bawah laut.

Politeknik Negeri Manado sesuai program pemerintah untuk Kampus Merdeka dan Merdeka Belajar, sudah mulai menerapkan program tersebut melalui proses belajar mengajar, demikian juga di Jurusan Akuntansi Politeknik Negeri Manado. Jurusan Akuntansi sesuai program tersebut dengan mengacu pada kurikulum pembelajaran dengan merancangkannya kedalam rencana kegiatan semester untuk pengenalan tentang dunia usaha dunia industri (DUDI), melalui program Case Method dan Project Based Learning. Proses pembelajaran tersebut di Jurusan Akuntansi mengacu pada proses pembelajaran berbasis program komputerisasi dalam bentuk E-learning Polimdo dengan panduan yang telah ditetapkan untuk selurug program studi yang ada di Politeknik Negeri Manado.

Visi Program Studi S1 Terapan Akuntansi Keuangan

Program studi akuntansi keuangan menjadi program studi sarjana terapan yang unggul dan terdepan dalam bidang Akuntansi Keuangan yang adaptif dan inovatif terhadap perkembangan serta penerapan ilmu pengetahuan dan teknologi yang berstandar internasional.

\section{Misi Program Studi S1 Terapan Akuntansi Keuangan}

1. Menyelenggarakan pendidikan bidang Akuntansi Keuangan untuk menghasilkan lulusan yang kompeten, memiliki semangat terus berkembang, bermoral, berjiwa kewirausahaan dan berwawasan lingkungan.

2. Melaksanakan penelitian terapan bidang Akuntansi Keuangan serta menyebarluaskan hasilnya untuk mengembangkan ilmu pengetahuan dan teknologi.

3. Melaksanakan kegiatan pengabdian kepada masyarakat bidang Akuntansi Keuangan melalui pemanfaatan ilmu pengetahuan dan teknologi untuk mendukung peningkatan mutu kehidupan. 


\section{Gambar 1. Struktur Organisasi Jurusan akuntansi Politeknik Negeri Manado}

Data yang dihasilkan pada bagian ini merupakan hasil wawancara terhadap mahasiswa Jurusan Akuntansi Program Studi (Prodi) S1 Terapan Akuntansi Keuangan Politeknik Negeri Manado. Berdasarkan data yang diperoleh dari pelaksanaan penelitian yang melibatkan 5 (lima) mahasiswa sebagai informan kunci (key informant), maka hasilnya dapat dideskripsikan sebagai berikut:

\section{Analisis Hasil Penelitian}

Mahasiswa akuntansi Jurusan Akuntansi Prodi S1 Terapan akuntansi Keuangan memiliki minat untuk mengikuti ujian sertifikasi Chartered Accountant (CA), merupakan sebuah perilaku yang dipengaruhi oleh minat individu berdasarkan faktor-faktor seperti faktor norma subjektif, sikap terhadap perilaku, dan kontrol perilaku persepsian. Hal ini sesuai dengan analisis atas hasil penelitian dari para informan kunci, yang dapat dideskripsikan dalam pengelompokan faktor-faktor tersebut, sebagai berikut:

\section{Faktor Norma Subjektif}

Norma subjektif yang menggambarkan pelaksanaan perilaku spesifik atas keyakinan seseorang dalam bertindak untuk menyetujui atau menolak dorongan dari pihak yang memberi referensi yang berhubungan dengan minat mengikuti ujian sertifikasi CA, dalam hal ini mahasiswa Jurusan Akuntansi Prodi S1 Terapan Akuntansi Keuangan Politeknik Negeri Manado sebagai informan kunci sebagian besar menyatakan atas dorongan dan kemauan dari diri sendiri (Informan Kunci Nomor 1, 2, 4, dan 5), disamping pengaruh dari keluarga juga dorongan para dosen (Informan Kunci 1). Munculnya suatu dorongan dan kemauan dari diri sendiri diawali oleh pengetahuan dalam proses pembelajaran selama melaksanakan perkuliahan dan ditunjang oleh informasi melalui sosialisasi secara meluas dan terorganisir dari Ikatan Akuntansi Indonesia. Sehingga menggambarkan dan menyatakan, bahwa dorongan dan kemauan itulah yang menjadi penentu kuat timbulnya minat untuk mengikuti ujian sertifikasi CA tersebut, yang secara tegas tanpa intervensi oleh siapapun.

\section{Sikap Terhadap Perilaku}

Sikap merupakan kecenderungan untuk bertindak secara positif atau negatif atas perilaku spresifik seseorang. Jika dianalisa dalam hubungannya dengan motivasi mahasiswa sebagai informan kunci, sehingga mengambil sikap untuk mengikuti ujian sertifikasi $C A$, yaitu disebabkan oleh pertimbangan bahwa jika memiliki gelar sebagai CA akan mempermudah dan berpeluang besar secara terbuka dalam kompetisi masuk dan berkarir di perusahaan lokal dan asing, akan lebih berkembang dan dapat mengembangkan dirinya sebagai akuntan secara global serta dianggap benar-benar sebagai seorang akuntan, lebih 
bernilai dalam dunia pekerjaan, kualifikasi sebagai akuntan profesional sesuai dengan standard internasional, dapat mempertinggi mutu pekerjaan dan menambah nilai atau manfaat karir di kemudian hari, mendapatkan gelar profesi di bidang akuntansi, dan kebutuhan sebagai syarat membuka Kantor Jasa Akuntansi (KJA) serta dapat mengambil keputusan lebih tepat dan akurat (Informan Kunci Nomor 1, 2, 4, dan 5).

\section{Kontrol perilaku persepsian}

Kontrol perilaku persepsian berfungsi sebagai peran yang berdasarkan ketetapan atau pengendalian keyakinan, seperti untuk mengikuti ujian sertifikasi CA yang memerlukan alokasi waktu dan biaya yang cukup besar serta jika sudah bekerja setelah lulus memerlukan perlakuan mengenai keputusan atas keyakinan memiliki minat untuk mengikuti ujian sertifikasi tersebut. Atas pernyataan para informan kunci setelah dianalisa mengenai masalah waktu dalam mengikuti ujian sertifikasi CA yaitu: tidak dipermasalahkan karena waktu bekerja sambil belajar dapat dilakukan secara bersama-sama, namun akan diatur waktu dengan baik; dan memilih menunda bekerja dulu karena ingin mempersiapkan diri dalam mengikuti ujian sertifikasi CA; sedangkan masalah biaya yang harus dikeluarkan dalam penyelenggaraan ujian sertfikasi CA tersebut sebagaian besar tidak mempermasalahkan karena dianggap merupakan hal yang wajar atas jumlah besaran biayanya dan untuk kedepan hasilnya akan sangat menunjang karir dan sangat memiliki nilai tambah dalam kompetensi berkarir (Informan Kunci Nomor 1, 2, 4, dan 5). Walaupun ada yang akan tertunda dalam mengikuti ujian sertifikasi karena terlebih dahulu berkeinginan untuk berkarir dalam pekerjaan, tapi sudah mempunyai suatu komitmen dengan keyakinan bahwa jika dikemudian hari memiliki penghasilan lebih akan ikut ujian sertifikasi CA (Informan Kunci Nomor 1).

\section{Simpulan dan Saran}

Berdasarkan hasil analisis atas penelitian yang sudah dilakukan terhadap minat mahasiswa akuntansi untuk mengikuti ujian sertifikasi CA, maka kesimpulannya adalah bahwa minat tersebut dipengaruhi oleh faktor norma subyektif yang meliputi suatu dorongan dan kemauan dari diri sendiri diawali oleh pengetahuan dalam proses pembelajaran selama melaksanakan perkuliahan dan ditunjang oleh informasi melalui sosialisasi secara meluas dan terorganisir dari IAI; faktor sikap terhadap perilaku yang meliputi mempermudah dan berpeluang besar secara terbuka dalam kompetisi masuk dan berkarir di perusahaan lokal dan asing, lebih berkembang dan dapat mengembangkan dirinya sebagai akuntan secara global seperti membuka Kantor Jasa Akuntansi serta memiliki gelar kualifikasi sebagai akuntan profesional sesuai dengan standard internasional; faktor kontrol perilaku persepsian yang meliputi ketetapan atas keyakinan mengikuti ujian sertifikasi walaupun memerlukan alokasi waktu dan biaya yang cukup besar, tidak dipermasalahkan karena waktu bekerja sambil belajar dapat dilakukan secara bersama-sama atau memilih menunda bekerja karena ingin mempersiapkan diri dalam mengikuti ujian sertifikasi CA dan jika tertunda masih tetap memiliki komitmen di kemudian hari, sedangkan masalah biaya dianggap merupakan hal yang wajar atas jumlah besaran biayanya.

Saran sebagai rekomendasi penulis bagi para mahasiswa akuntansi yaitu untuk lebih memperluas pengetahuan mengenai peranan CA dan lebih mengembangkan pengetahuan dan teknologi bidang akuntansi sebagai kompetensi utama yang berstandar internasional, sedangkan saran bagi Instansi Politeknik Negeri Manado yaitu: agar memberikan motivasi kepada mahasiswa untuk lebih mengembangkan diri sesuai Visi Politeknik Negeri Manado yaitu agar lebih unggul dan terdepan dalam bidang akuntansi keuangan yang adaptif dan inovatif terhadap perkembangan serta penerapan ilmu pengetahuan dan teknologi yang berstandar internasional.

\section{Daftar Pustaka}


Abidin, A. Z., \& Ervanto, adi darmawan. (2015). Pengaruh Motivasi Terhadap Minat Mahasiswa Akuntansi Mengikuti Ujian Certified Public Accountant ( Cpa ). Jaffa, 03(1), $55-68$.

Agustina, \& Yanti, D. M. (2015). Analisis Faktor-Faktor yang Mempengaruhi Tingkat Pemahaman Akuntansi Mahasiswa Jurusan Akuntansi STIE Mikroskil Medan. Jurnal Wira Ekonomi Mikroskil, 5(1), 11-20.

Ajzen. (2012). The Theory of Planned Behaviour. Sage. London.

Al-Smadi, M. \& S. A. A.-W. (2012). The Impact of E-Banking on the Performance of Jordanian Banks. Journal of Internet Banking and Commerce, vol 29, 130141.

Hidayat, Syarif, \& Asroi. (2013). Manajemen Pendidikan Substansi dan Implementasi dalam Praktik Pendidikan di Indonesia. Pustaka Mandiri. Tanggerang.

IAI. (2014). Fungsi dan Posisi CA. In Iai (p. 1). Diakses melalui http://iaiglobal.or.id/v03/CA/fungsi-dan-posisi-ca.

IAI. (2014). Visi \& Misi IAI - IAI Global (p. 1). Diakses melalui http://iaiglobal.or.id/v03/tentang_iai/visi-misi

IAI. (2019). Menjadi Akuntan Profesional (CA). Diakses melalui http://www.iaiglobal.or.id/v03/CA/menjadi-CA

Ilmiha, \& Syafrizal. (2017). Biaya Pendidikan Sebagai Pemoderasi Pengaruh Motivasi Karir Dan Motivasi Ekonomi Terhadap Minat Mahasiswa Akuntansi Mengikuti Pendidikan Profesi Akuntansi. Jurnal Akuntansi, 4(3), 588-615.

Peraturan Pemerintah Republik Indonesia Nomor 4 Tahun 2014 tentang Penyelenggaraan Pendidikan Tinggi dan Pengelolaan Perguruan Tinggi, (2014).

Kementrian keuangan. (2012). Undang-Undang Republik Indonesia No 12 Tahun 2012 (pp. $1-41)$.

Peraturan Menteri Keuangan Republik Indonesia Nomor 25 /PMK.01/2014 tentang Akuntant Berigester Negara, 1 (2014).

Laksmi, A. C., \& Suciati, I. (2018). Factors Influencing the Intention to Obtain Accountant Certifications. The Indonesian Journal of Accounting Research.

M.N. Mukmin, H. W. (2017). Akuntabilitas Kinerja Akuntan Pendidik Berdasarkan Kompetensi Akuntan Ddan Etika Profesional ( Studi Empiris Pada Perguruan Tinggi Swasta di Bogor ). Jurnal AKUNIDA, 3, 242-303.

Maulana Saud, I. (2016). Pengaruh Sikap dan Persepsi Kontrol Perilaku Terhadap Niat Whistleblowing Internal-Eksternal dengan Persepsi Dukungan Organisasi Sebagai Variabel Pemoderasi. Jurnal Akuntansi Dan Investasi, 17(2), 209-219.

Mihartinah, D., \& Coryanata, I. (2019). Pengaruh Sikap Terhadap Perilaku, Norma Subjektif, Dan Kontrol Perilaku Persepsian Terhadap Niat Mahasiswa Akuntansi Untuk Mengambil Sertifikasi Chartered Accountant. Jurnal Akuntansi, 8(2), 77-88.

Nuraina Elva, \& Septi Hari Kurniawati. (2012). Perbedaan Persepsi Akuntan Publik, Akuntan Pendidik, Dan Mahasiswa Akuntansi Terhadap Kode Etik Ikatan Akuntan Indonesia. 
Jurnal Akuntansi Universitas Jember, 9(1), 98.

Riswandari, E. (2017). Persepsi Mahasiswa Akuntansi Universitas Bunda Mulia Tentang Faktor-Faktor. Akuntansi Bisnis, 2(2), 1-26.

Sapitri, \& Yaya. (2015). Faktor-Faktor Yang Berpengaruh Terhadap Minat Mahasiswa Untuk Mengikuti Pendidikan Profesi Akuntansi (PPAk). Jurnal Akuntansi \& Investasi, 16(1), 46-61.

Saraswati, \& Baridwan. (2012). Penerimaan Sistem E-Commerce : Pengaruh Kepercayaan, Persepsi Manfaat Dan Persepsi Resiko. Journal Ilmiah Mahasiswa FEB, 1-19.

Schunk, D. H. (2012). Learning Theories: An Educational Perspectives (6 edition). Pearson Education Inc. New York

Slameto. (2013). Belajar dan Faktor-Faktor Yang Mempengaruhinya. PT. Rineka Cipta. Jakarta.

Sumaryono, \& Sukanti. (2016). Faktor-Faktor Yang Mempengaruhi Niat Mahasiswa Akuntansi Untuk Mengambil Sertifikasi Chartered Accountant. Jurnal Profita, 7(4), 120 .

Vidalita. (2015). Faktor-Faktor Yang Mendorong Mahasiswa Mengikuti Pendidikan Profesi Akuntan dan Chartered Accountant (Survei Pada Mahasiswa PPAk di Malang). Jurnal Ilmiah Mahasiswa FEB (JIMFEB), 53(5), 1-116.

Wanarta, F. E., \& Mangoting, Y. (2014). Pengaruh Sikap Ketidakpatuhan Pajak, Norma Subjektif, dan Kontrol Perilaku yang Dipersepsikan terhadap Niat Wajib Pajak Orang Pribadi untuk Melakukan Penggelapan Pajak. Tax \& Accounting Review, 4(1), 138. 